\title{
Energy Mix as a Driver of Sustainability in the South African Energy Supply Chain
}

\author{
Kenneth Mathu \\ University of Pretoria: Gordon Institute of Business Science
}

The fossil fuel dominated South African energy industry is undergoing significant transformation with introduction of renewable energy and clean coal technologies. Coal is the primary source of energy producing $88 \%$ of the total electricity generation and $40 \%$ liquid fuels. The study aimed to establish that the addition of cleaner energy sources would drive sustainability in the energy supply chain. Sustainability is the underpinning theory and a qualitative methodology was pursued. The energy industry professionals were interviewed, data transcribed and thematically interpreted via content analysis. The results established that the addition of cleaner sources of energy increased the consistency of energy supply, reduced power outages, and reduced carbon emissions drastically, rendering the energy supply chain more sustainable.

\section{INTRODUCTION}

Since the first industrial revolution, energy use has been an integral component of economic development in the world. Coal is one of the leading sources of energy in the world contributing $41 \%$ of the total global electricity production (World Bank Report, 2015). It is used in the heavy industries as a heat generating catalyst (coking), and at home for space heating and cooking. In South Africa, coal is the primary source of energy contributing $88 \%$ of the country's electricity generation and $40 \%$ of the national liquid-fuels production (DMR, 2009).

The global coal producing countries strive to maintain the ever-rising energy demand that emanated from rising population and rapid industrialization (BP Energy Stats Review, 2017). The volatile energy demand required a suitable supply model to satisfy the present and the future requirements (Holldorsson \& Svanberg, 2013).

Despite its adversity in carbon emissions, coal will remain a dominant source of energy for generations to come in many countries including South Africa (Baxter, 2015). South Africa has abundant reserves of coal that exists in situ, and at the current rate of exploitation, it could last over 200 years (Thopil \& Pouris, 2010). The country is home for some of the largest coal mines and has the largest coal export terminal in the world (SA Chamber of Mines, 2016). The South African coal is used $75 \%$ for domestic market and 25\% for export market (DMR, 2009).

The South African energy supply chain is destined for significant transformation as the country's National Development Plan-2030 (NDP) aims to reduce reliance on coal by including renewable sources and additional nuclear power in the new energy mix (NDP, 2011). The NDP has ambitious targets aimed at reducing carbon emissions by use of clean coal technologies in the new coal-fired power stations and 
mechanism to reduce emissions from the existing power stations, enhanced development for renewable sources of energy and additional nuclear power plants (NDP, 2011).

The constraints for relying on coal for energy provision culminated with the country's first power outages in 2007/2008, that has now been almost fully contained. The crisis emanated mainly from the ageing power infrastructure, and lack of fresh investments in the industry for over a decade (NERSA 2009). The deficiency in the electricity supply chain was being addressed through the national contingency plan under the auspices of the Integrated Resource Plan (IRP, 2010) by the Department of Energy, and the country's National Development Plan (NDP, 2011). The strategy included the completion of two giant coal-fired power stations namely Medupi and Kusile that will utilize clean coal technologies, and development of independent power producers (IPPs) under the government initiative of renewable energy independent power producers' procurement program (REIPPPP).

The underpinning theory of the study was sustainability: delving on the use of resources for power generation that meet the present needs without compromising on the capacity of the future generations by intensifying use of renewable energy.

\section{THEORETICAL GROUNDING}

This study was grounded on the 1987 Brundtland Report on 'Sustainable Development' theory delivered at the United Nations World Commission on Environment and Development. The report defined sustainable development as:

"development that meets the needs of the present without compromising the ability of the future generations to meet their own needs" (Johnston, Everard, Santillo \& Robert, 2007). It compares with the scientific model of sustainability that has linkages (dependencies), and feedback effects between environment, society, and economy (Epstein \& Buhovac, 2014).

The analogy to this study is the importance of South Africa accelerating development of multiple sources of energy to avoid the present state of over-reliance on fossil sources. The practice involves building additional renewable energy sources, use of clean coal technologies in new coal-fired power stations, installing pollution controls in the old coal-fired power stations, and building additional nuclear power stations when economically feasible. This would culminate into an energy supply chain with less carbon emissions, and consistent energy supply due to use of multiple sources that would ultimately lead to supply chain sustainability.

\section{COAL MINING AND CONSUMPTION}

The bulk of South African coal is produced by five leading multinational firms that together produce $84 \%$ of the total coal production in the country. The companies are Anglo Coal, Sasol, BHP Billiton, Glencore, and Exxaro. The other $16 \%$ of coal is produced by junior miners that included upcoming black economic empowerment (BEE) companies (Oberholzer, 2014).

The South African coal production is predominantly for domestic use for electricity generation, liquid fuels and petrochemicals production that comprised $75 \%$ of the total production, and the other $25 \%$ is for export. The state-owned entity electricity company of South Africa (Eskom) consumes $70 \%$ of the total domestic consumption for the generation of electricity, while South African synthetic oil company (Sasol) consumes $20 \%$ in the production of liquid fuels and petrochemicals. The usage of the other $10 \%$ is broken down into (5\% general industry, $3 \%$ merchants, and 2\% home use) (DoE, 2011).

\section{Electricity Generation by Eskom}

The coal-fired power stations have 'tied-colliery' type of contracts with adjacent coal mines in the Highveld region in Mpumalanga province that facilitate use of conveyor belts for the ease of transportation costs (Eskom, 2009). It was only in the last decade or so when the power stations had to acquire top-up capacity from the coal mines in the periphery via road transport, as coal depletion hit the region around the 
same time (Prevost, 2010: 17). The transportation of coal by road has become a major environmental issue due to excessive pollution. That level of pollution could only be controlled by converting into a more feasible, and environmentally friendly transport mode such as rail or relocation of the power stations to the more resourceful fields at Waterberg coalfields in Limpopo Province (Ryan, 2014). However, the longterm plan is to relocate the coal-fired power stations to Waterberg coalfields after the present power stations are decommissioned as they have approached end of life. The relocation would require improved infrastructures such as water, rail and road (Lazenby, 2012).

Eskom operates a nuclear plant at Koeberg, Cape Town that generates 5\% (1800 MW) of the total electricity generation capacity, and there are plans to build three new nuclear plants when budget allows, and they have a total generation capacity of 9600 MW (Mining Weekly, 2016).

\section{Clean Coal Technology Use in New Coal-Fired Power Stations}

The two new massive coal-fired power stations under construction by Eskom: Medupi and Kusile are designed to utilize new coal technologies of super-critical, and ultra-super-critical respectively, that will drastically reduce carbon emissions. Medupi has six units with a total generation capacity of $4764 \mathrm{MW}$, while Kusile also has six units with a total generation capacity of $4800 \mathrm{MW}$ (Eskom, 2016). Most of the old coal-fired power stations are approaching the end of life, and they would be decommissioned in the next ten or fifteen years. However, despite the old age, most of them have been retrofitted with bag filters to control particulate, and carbon emissions (Eskom, 2009).

The new build and the refurbishing of the old coal-fired power stations are geared for generation efficiency, and reduction of carbon emissions that will drive sustainability in the South African energy supply chain.

\section{Liquid Fuel or Synthetic Fuel Production by Sasol}

Sasol operates its own coal mines that produce coal for conversion into synthetic fuels or liquid fuel through coal-to-liquid (CTL) and gas-to-liquid (GTL) processes that contribute $40 \%$ of the country's total liquid fuels requirements (Sasol, 2015). The Sasol plant at Secunda imports most of the natural gas feedstock from Mozambique via $850 \mathrm{~km}$ pipeline. Some of the coal from the Sasol coal mines is exported, while some stock is used to generate steam for internal operations (Sasol, 2008). That implied a short supply chain for the bulk of the coal produced, while a smaller portion is for the longer and lucrative export supply chain (Sasol, 2008).

\section{Coal for Export}

A quarter of the total coal produced in South Africa is exported to earn the country's much needed foreign exchange. The coal export supply chain is longer, and the mode of transportation of $650 \mathrm{~km}$ rail line from Ermelo in Mpumalanga to the Richards Bay Coal Terminal (RBCT) along the Indian ocean coastline. The export destination is the European Union (EU) countries, India and Middle East (Burkhardt, 2015). The RBCT with present handling capacity of 91 million tons per annum is the leading coal export terminal in the world (RBCT 2015).

\section{The Addition of Renewable Sources of Energy Mix}

The inclusion of renewable sources of energy by independent power producers (IPPs) is a game changer to the South African energy supply chain. Its significance is in provision of clean energy with reduction of carbon emissions. The low level of carbon emissions would position the country better in the global crusade against the climate change phenomenon as stipulated by the first United Nations earth summit at Rio de Janeiro in 1992 (UNCED, 1992).

The emergence of the IPPs was initiated by the private sector to fill the gap in the electricity market, and the desire to be part of the solution of the energy shortage that commenced in 2007. The IPPs are supported by the law that allows $30 \%$ of power generation from private sector from renewable sources and $70 \%$ by the state entity Eskom (DoE, 2006). Further support for IPPs followed in 2011 when the government adopted an economic development blueprint under the auspices of 'National Development Plan 2030' (NDP 
2030). Regarding the energy issues, the NDP stated that South Africa would by 2030 be able to procure $20000 \mathrm{MW}$ of renewable electricity, decommission $11000 \mathrm{MW}$ of aged coal-fired power plants and have increased demand side savings. It also stated that $90 \%$ of South Africans should have access to electricity by 2030 (NDP, 2011).

The government initiative of "renewable energy independent power producer procurement program" (REIPPPP) is accelerating the development of renewable sources mainly solar, wind, and biomass energy projects (Eberhard \& Kolker, 2014). A prerequisite to increase generation capacity, and optimtize accessibility by the citizens required the national grid to be opened to IPPs. Indeed, plans are at an advanced stage for upgrading the grid to meet the increasing generation capacity.

South Africa's current transmission architecture is a single buyer model (Jamasb, 2006). A single buyer model is one through which an independent entity purchases electricity from generators, and sells to the distribution network. Under the prevailing situation, Eskom is the single entity that purchases power and at the same time it owned majority of the distribution network.

Hence, it is paramount for the inclusion of IPPs to increase the energy mix in meeting the strategies of NDP, and integrated resource planning (IRP) which are pushing for sufficient clean energy for the present, and the future. Besant-Jones, (2006) expressed four ways that supported the private sector involvement as follows:

- "The state utility Eskom delegating management of some of its operations to an external company would delegate part or all its operations to an outside party.

- The state would provide lease and concessions of the assets, but remain owners of the assets, and would not be directly involved in their management, and operation.

- Eskom would cease to be a monopoly by transferring ownership of some of its assets to a third party.

- The state would allow new assets into the electricity market through third party arrangements through creation of IPPs that would be delegated a certain generation quota as it is presently".

Presently, Eskom is the only power purchaser from IPPs as indicated by the architecture of the South African electricity sector.

\section{NATIONAL DEVELOPMENT PLAN 2030 (NDP)}

The National Development Plan (NDP) recommended the following objectives for energy enhancement goals by 2030 :

'people with access to the grid should be 90\%; procurement of $20000 \mathrm{MW}$ from renewable sources; decommissioning $11000 \mathrm{MW}$ of aged coal fire power plants; transition to a low carbon economy; demand side savings by installing five million solar water heaters; simplifying the regulatory regime to encourage renewable energy, and independent power producers (IPPs)' (NDP, 2011).

The NDP also recognizes the need to move to a low carbon economy and estimated that an additional $29000 \mathrm{MW}$ of electricity was required by 2030 . Also included in the plan was building of $40000 \mathrm{MW}$ of additional capacity of which at least $20000 \mathrm{MW}$ would be renewable energy. The government pledged support for IPPs development by launching their procurement program that was attractive to investors in the industry. (NDP, 2011). The implementation of the NDP energy policy would accelerate development of multiple sources of energy especially the cleaner and more affordable renewable sources, that would drive sustainability in the energy supply chain.

\section{MINERAL AND PETROLEUM RESOURCES DEVELOPMENT ACT (MPRDA) OF 2002}

The Mineral and Petroleum Development Act (MPRDA)of 2002 is the legislation that directs the South African mining industry. Its objective is to drive socio-economic development agenda that aim to 
promote equitable access to mineral, and petroleum resources, with a focus on expanding opportunities to historically disadvantaged persons. That entailed promoting the economic growth, increasing employment opportunities, development of downstream industries, and managing the use of the country's resources in an ecologically sustainable manner (DMR, 2002).

However, the Act contains some ambiguous clauses hitherto unresolved. For instance, the ministerial responsibilities were unclear in stipulating the requirements for promoting rights, and interests of stakeholders such as communities, and investors (DMR, 2016). Indeed, one of the priorities of the new South African government effective February 2018 is to streamline the Act to expedite meeting the socioeconomic objectives, as well as remaining investor friendly (Gore \& Pienaar, 2018).

\section{FUTURE ENERGY MIX}

The South African energy mix will continue to be dominated by fossil-based sources (coal, oil and gas) at a reduced level, as renewable sources contribution would continue rising (NDP 2011). The following table show the projections of the South African future energy mix.

TABLE 1

\section{PROJECTION OF SOUTH AFRICA'S FUTURE ENERGY}

\begin{tabular}{|l|l|l|l|l|}
\hline Technology & 2015 & 2030 & Load Type & Producer \\
\hline Coal & $90 \%$ & $65 \%$ & Base & State \\
\hline Nuclear & $5 \%$ & $20 \%$ & Base & State \\
\hline Renewable & $0 \%$ & $9 \%$ & Peak & Private \\
\hline Hydro/Gas & $5 \%$ & $6 \%$ & Peak & State \\
\hline
\end{tabular}

Source: (DoE, 2011)

The above table indicates that the reliance on coal for the generation of electricity would fall from $90 \%$ to $65 \%$ by 2030 while the renewable sources and nuclear power would rise by $10 \%$ and $15 \%$ respectively. However, the projection since 2011 changed with IPPs being allocated $2500 \mathrm{MW}$ of electricity cogeneration from coal using clean coal technologies (DoE, 2014). In pursuance of this objective, the South Africa's new Minister of Energy has given green light for the implementation of 27 renewable energy projects that had stagnated for over two years due to political uncertainty (DoE, 2018).

\section{CARBON EMISSIONS}

South Africa is ranked number 14 among the global top 20 leading carbon emitting countries (Union of Concerned Scientists, 2015), with Eskom as the leading emitter in the country followed by Sasol (Mckenzie, 2011). Sasol's Secunda plant at Sasolburg is the leading single carbon emitter in the Southern Hemisphere (Sasol, 2008: 36). The government has set emission standards for companies which are heavy in carbon emissions such as coal-fired plants, petrochemicals, cement, smelters and others (DW \& EA, 2010).

However, South Africa subscribes to the United Nations Framework Convention on Climate Change (UNFCCC) that leads the campaign against the global phenomenon of climate change or global warming (UNFCCC, 2009). The climate issues commenced with the first 'Earth' meeting in Rio de Janeiro, Argentina in 1992, followed by the Japan treaty, (Kyoto Protocol, 1997). The latest development that has attracted the global leading carbon emitters China and United States was the Conference of the People (COP21) in Paris, France in 2015 (Mitchell \& Mitchell, 2016).

South Africa has an ambitious target of decarbonization of between 3.3\% to 5\% per annum that translates to $398 \mathrm{MtCO} 2 \mathrm{e}$ (Million tons of carbon-dioxide equivalent) (BP Energy Stats Review, 2015). It is against this background that accelerating development of multiple sources of energy (increasing the renewable sources, and reducing coal use), use of clean coal technologies in the new build, and 
refurbishing the old coal-fired power stations to control emissions, that would render sustainability in energy supply chain in South Africa.

\section{PROBLEM STATEMENT}

The implications were sought in diversifying energy sources from the predominantly fossil sources by building renewable sources, additional nuclear power plants, and use of clean coal technologies. Essentially, the ability to establish sustainability of the energy supply chain, and reduction of carbon emissions.

\section{EMPIRICAL OBJECTIVES}

The study aimed to establish the following:

- Consistency in the availability of energy by increasing the South African energy mix with renewable sources, nuclear, and use of clean coal technologies.

- Realize sustainability of energy supply chain with reduced carbon emissions by accelerating development of renewable sources of energy, use of clean coal technologies in the new coal-fired power stations, and refurbishing of the old coal-fired power stations.

\section{RESEARCH METHODOLOGY AND DESIGN}

The study pursued a qualitative research methodology to achieve its objectives. Lee and Lings (2008) described qualitative research as the process of a researcher generating data from the interviews conducted with the respondents. The research design entails the processes pursued to achieve the intended outcome of the study. Saunders and Lewis (2012), described research design as understanding the purpose of the research, pursuance strategy, and ability to attain credibility of the interviews, as their outcome must be acceptable and reasonable.

This study aimed to establish the benefits accrued by accelerating development of multiple sources of energy in the South African energy supply chain. This is crucial as fossil fuels are the dominant sources, and they are heavy in carbon emissions. Thus, speeding up development of renewable sources, and the use of clean coal technologies which has minimal carbon emissions is paramount. The other crucial aspect is that energy supply from more than one source becomes more consistent as all sources are unlikely to fail at the same time. Consequently, you would achieve sustainability in the energy supply chain. Hence, exploratory approach of the energy industry role players both public, and private sectors provided insights for this research. Under the circumstances, qualitative research paradigm was ultimately the most appropriate method for the study.

The participants in the study were top professionals in the energy industry that is dominated by Eskom's fleet of coal-fired power stations, a nuclear plant, and some plants for renewable energy. Also included were other state role players that comprised rail logistics (Transnet), Department of Energy (DoE) and the National Energy Regulator (NERSA). The private sector participants comprised coal mines, renewable energy enterprises or independent power producers (IPPs), and energy consultants. The 14 participants drawn from across the energy industry represented over $95 \%$ of the serious industry players in the country.

A semi-structured questionnaire was used, and interviews lasting one hour were recorded using a digital data recorder. The respondents were briefed in advance on the purpose of the interviews which were conducted at their premises. Saunders and Lewis, (2012) affirmed the briefing of participants before the interview. The gate-keepers at the institutions, and enterprises involved assisted in arranging for the interviews with the respondents. In preparations to gain access to the targeted participants, the value proposition of the study was presented to the gate-keepers telephonically, and via e-mail.

The recorded interviews were then transcribed, analyzed, coded and interpreted via content analysis. The emerging major themes, and sub-themes provided the outcome of the study. Hence, thematic content 
analysis was applied for data analysis. A field notebook used to record the interviews eventually provided comparisons with the transcriptions to ascertain validity, and trustworthiness of the data. The literature, data collected, and the field notebook containing interview inputs provided triangulation of the study.

Undertaking research in an ethical manner is paramount (Kumar, 2005). In this instance, the researcher presented to the respondents a written undertaking from the sponsoring institution, stipulating the confidentiality undertaking of non-disclosure, and anonymity of the respondents during the interview period and afterwards.

\section{RESULTS}

The results of the study were expressed by the findings as follows:

Seven major themes, and several sub-themes emanated from the study, and supported the objectives set up. The major themes comprised: coal is heavy in carbon emissions, intermittent nature of renewable energy, energy mix, transforming energy supply chain, energy pricing (electricity and gasoline), emergence of independent power producers (IPPs), and regulations and policy. The several sub-themes that emerged also complemented the major themes. These themes represent the views of the respondents during the interview, and they provided answers to the empirical objective of the study.

\section{The Study Realized the Set Up Empirical Objectives as Stated:}

- Empirical objective 1: "Consistency in the availability of energy by increasing the South African energy mix with renewable sources, nuclear, and use of clean coal technologies".

Most of the respondents (12) agreed that speeding up multiple sources of energy, and specifically referring to the renewable sources: solar, wind, hydro and biomass would be the best way to avoid power outages as multiple sources cannot fail at the same time. They expressed that over-reliance on one source (coal) is risky, hence the country has experienced power outages since 2007. They expressed hope that development of the renewable sources would be expedited. The renewable sources provided cleaner energy as it had minimal carbon emissions. There was more flexibility in energy provision from more than one source that in the long run led to more competitive prices and drastically minimized power outages. In view of this, Respondent 7 stated: "the sooner we liberalize our electricity market, level the playing fields, introduce an independent system and market operator, encourage the wide spread use of IPPs, introduce an energy market, and get rid of the command and control economy which we are stuck in at the moment, the better it will be for this economy." Indeed, solar and wind power were the latest addition to the grid, as nuclear already existed and preparations for the new nuclear build were at an advanced stage.

- Empirical objective 2: "Realize sustainability of energy supply chain with reduced carbon emissions by accelerating development of renewable sources of energy, use of clean coal technologies in the new coal-fired power stations, and refurbishing of the old coal-fired power stations".

Ten respondents emphasized on this objective as they expressed the need to fast-track the renewables sources, use of clean coal technologies, and the refurbishing of the old coal-fired power stations to reduce carbon emissions. They expressed the bad positioning of South Africa in carbon emissions globally. Five of them were critical about the state monopoly in energy provisions, and the slow pace of development of renewable sources. Three of the respondents expressed concerns why they are restricted to the development of renewable energy only. There was a consensus between the respondents on the urgent need to reduce reliance on coal for the generation of electricity due to the underlying risk of a single source, and heavy pollution among others. Indeed, the NDP also recommended future scaling down on coal use from the current $90 \%$ to $65 \%$ by 2030 and increase renewable energy by $10 \%$ and nuclear by $15 \%$ as indicated in the literature. 
The respondents stated that diversity in energy suppliers reduced the chances of power outages. The base load role of coal could also be played by nuclear energy as the intermittent nature of the renewable energy rendered it unsuitable. The diversity of energy suppliers with higher generation capacity would stimulate the energy supply chain as opposed to the monopoly of the industry by the state with fossil sources.

Reduced reliance on coal also meant a drastic reduction in carbon emissions. Five respondents expressed some good performance by Eskom in using clean coal technologies in the construction of the two new coal-fired power stations: Medupi and Kusile that will utilize supercritical and ultra-supercritical technologies respectively, aimed to drastically reduce carbon emissions on completion. They also commended Eskom for striving to refurbish the old coal-fired power stations to curb emissions. However, some of them felt that they should also be allowed to venture in power generation from fossil sources using the clean coal technologies.

Respondent 3 stated: "Obviously the carbon emissions would be great benefit in increasing renewable sources but the practicality of that, I don't think it's been thought through properly. The bigger the percentage renewable, the more instability there is on our grid, and that is going to create problems, there isn't enough places to connect onto the grid".

Reducing reliance on coal use meant reduction in carbon emissions and lower carbon footprint for products emanating from South Africa.

Respondent 11 expressed economic spin-off from IPPs: "In an IPP environment the shareholder takes the responsibility, there are no cost overruns, there's only one person that pays for those cost overruns, the shareholder, because the price of electricity is determined by contracts, by long term power purchase agreements. The sooner we liberalize our electricity market, level the playing fields, introduce an independent system and market operator, encourage the wide spread use of IPPs, introduce an energy market, and get rid of the command and control economy which we are stuck in at the moment, the better it will be for this economy."

The IPPs increased the energy mix in the energy supply chain that rendered the value chain more flexible as opposed to reliance on coal only.

\section{LIMITATION TO THE STUDY}

The energy sector is a specialized and a sensitive field due to its critical role in national development. Hence, the role players are limited, although the impact is massive. The respondents demanded strict confidentiality for their disclosure, and it was provided. As the industry is predominantly state controlled, red tape was a barrier which was overcome through negotiations with the gate-keepers who provided permission to contact the responsible executives.

\section{CONCLUSION}

The study explored the energy industry and the domination of energy supply from fossil sources for electricity generation through the state entity Eskom, and for liquid fuel production by Sasol. The incorporation of renewable sources of energy in the energy supply chain from 2006 when IPPs were allowed by the electricity Act to commence provisions of $30 \%$ of the national electricity capacity was reviewed. The energy regulations and policies from Department of Energy: Integrated Resource Planning (IRP), National Development Plan 2030 (NDP), the cumbersome Mineral and Petroleum Resource Development (MPRDA) Act of 2002, and the environmental legislation were explored. The South African abundant coal reserves, dangers of carbon emissions, and the role of the United Nations body UNFCCC on climate or global warming were also reviewed.

The measures being taken to accelerate development of renewable sources of energy in pursuit of multiple sources of energy that would maintain a consistent clean energy supply chain were studied. This included the use of clean coal technologies in the construction of the new power stations, and the 
refurbishing of the old coal-fired power stations to control carbon emissions. Also included was the South African government's REIPPPP initiative to accelerate the IPPs development in the electricity sector.

Subsequently, the two empirical objectives set up for the study were achieved as stipulated in the results.

\section{RECOMMENDATIONS}

Having stipulated the importance of accelerating development of multiple sources of energy in South Africa, recommendations are made as follows:

- Fast track implementation of NDP 2030 to steadily increase the energy mix geared to reduce carbon emissions, and provision of consistent energy supply to stop power outages.

- MPRDA Act be revised after enough consultation with the role players in energy industry to ensure it is acceptable by all stakeholders including investors.

- IPPs coal cogeneration could be enhanced to boost foreign direct investments (FDIs);

- Pave way for future public-private partnership (PPP) for state utility company Eskom.

Expediting pursuance of these recommendations would stop the menace of power outages, drastically reduce carbon emissions, and significantly increase electricity generation capacity, making South Africa a low carbon economy. Enhanced clean coal technologies would turnaround the economy by utilizing the country's abundant coal resources better, attract FDIs and pave way for sustainable development that would steadily hike the gross domestic product (GDP).

\section{REFERENCES}

Baxter, B. (2015). South Africa's new coal policy. World Coal, 24, (6), 14-18, June.

Besant-Jones, J. E. (2006). Reforming Power Markets in Developing Countries: What have we learned? Energy and Mining sector board discussion, pp. 1-176, September.

BP Statistical Energy Review. (2015). [Online]. Available at: https:/www.bp.com/content/dam/bp/pdf/energy-economics/statistical-review-2015/bp-statisticalreview-of-world-energy-2015-full-report.pdf. Accessed: 2018-01-08.

BP Statistical Energy Review. 2017. [Online]. Available at: https://www.bp.com/content/dam/bp/en/corporate/pdf/energy-economics/statistical-review2017/bp-statistical-review-of-world-energy-2017-full-report.pdf. Accessed: 2018-01-06.

Burkhardt, P. (2015). South Africa's Richards Bay coal exports rise to a record in 2015. [Online]. Available at: https://www.bloomberg.com/news/articles/2016-01-19/south-africa-s-richards-baycoal-exports-rise-to-record-in-2015. Accessed: 2018-03-18.

Chamber of Mines of South Africa. (2016). Annual Report.

Eberhard, A. \& Kolker, J. (2014). The South Africa's renewable energy IPP programme: Success factors and lessons. [Online]. Available at: http://www.gsb.uct.ac.za/files/ppiafreport.pdf. Accessed: 2017-09- 22.

Epstein, M. J. \& Buhovac, A. R. (2014). Making Sustainability Work: Best Practices in Managing and Measuring Sustainability. San Francisco, CA: Berrett-Koehler.

Eskom. (2009). Integrated Report.

Eskom. (2016). Medupi, Kusile, and the massive cost/time overrun. [Online]. Available at: https://www.dailymaverick.co.za/article/2016-07-07-medupi-kusile-and-the-massive-costtimeoverrun/\#.WlEp0aiWbIU. Accessed: 2018-01-06.

Gore, S. \& Pienaar, A. (2018). Overhaul of financial provision regime takes a step in the direction of MPRDA legal certainty. [Online]. Available at: https://www.cliffedekkerhofmeyr.com/en/news/publications/2018/Corporate/mining-and-mineralsalert-5-february-overhaul-of-financial-provision-regime-takes-a-step-in-the-direction-of-legalcertainty.html. Accessed: 2018-03-17. 
Halldorsson, A. \& Svanberg, M. (2013). Energy resources: trajectories for supply chain management. Supply Chain Management: An International Journal, 18, (1), 66-73. [Online]. Available at: http://www.emeraldinsight.com/doi/abs/10.1108/13598541311293186. Accessed: 2017-09-18.

Jamasb, T. (2006). Between the state and market: Electricity sector reform in developing countries. Utilities Policy, 14, (1), 14-30.

Johnston, P., Everard, M., Santillo, D. \& Robert, K-H. (2007). Reclaiming the definition of sustainability. [Online]. Available at: https://link.springer.com/article/10.1065\%2Fespr2007.01.375?LI=true. Accessed: 2018-01-06.

Kumar, R. (2005). Research Methodology: A step by step guide for beginners. 2nd Edition. London: Sage.

Kyoto Protocol. (1997). United Nations Treaty on global climate change. Kyoto, Japan.

Lazenby, H. (2012). Ferrum iron-ore study delayed building Waterberg infrastructure solution. Mining Weekly. (2016). [Online]. Available at: http://www.miningweekly.com/article/ferrum-delaysiron-ore-study-pending-waterberg-infrastructure-solution-2012-03-16. Accessed: 2017-10-09.

Lee, N. \& Lings, I. (2008). Doing Business Research: A g Guide to Theory and Practice. London: Sage.

Mckenzie, M. (2011). Top carbon emitters in South Africa. [Online]. Available at: http://www.urbanearth.co.za/articles/top-carbon-emitters-south-africa. Accessed: 2018-01-06.

Mining Weekly. 2016. South African gold mining company Sibanye expressed disappointment that the draft revised Mining Charter was gazette without prior consultation. [Online] Available at: http://www.miningweekly.com/article/miners-react-to-go-it-alone-zwane-2016-04-18. Accessed: 2017-10-19.

Mitchell, JV \& Mitchell, B. (2016). Paris mismatches: The impact of the COP21 climate change negotiations on the oil and gas industries, 11 August. [Online]. Available at: https://www.chathamhouse.org/publication/paris-mismatches-impact-cop21-climate-changenegotiations-oil-and-gas-industries?gclid=Cj0KEQjwyJi_BRDLusby7_S7zIBEiQAwCVvnxyWYmi47_fRQMaAiZX3v0ch73z6lz-PwS9HDZjJCIEaAIDD8P8HAQ. Accessed: 2017-10-19.

National Development Plan. (2011). South African Government National Development Plan (Vision for 2030). Pretoria: Government Printer.

National Energy Regulator of South Africa (NERSA). (2009). Annual Report

Oberholzer, J. (2014). South African thermal coal: A burning issue. Johannesburg: Macquarie First South Securities.

Prevost, X. (2010). A clean future for coal. Inside Mining pp. 14-17, April/May.

Republic of South Africa. Department of Mineral Resources. (2002). Mineral and Petroleum Resources and Development Act. Pretoria: Government Printer.

Republic of South Africa. Department of Energy. (2006). Electricity Regulation Act of 2006 Section 34 (1). [Online]. Available at: www.fossilfuel.co.za/.../Presentation-on-the-IRP-and-IEP-to-the-FFFCouncil-23Septe. Accessed: 2017-10-02.

Republic of South Africa. Department of Mineral Resources. (2009). Growth Prospects of South Africa's Coal Exports. Pretoria: Government Printer.

Republic of South Africa. Department of Water and Environmental Affairs. (2010). Air Quality Act, 2004 Act No. 39 (Minimum Emissions Standards).

Republic of South Africa. Department of Energy. (2011). Integrated Resource Plan (IRP) for Electricity 2010-2030. Pretoria: Government Printer.

Republic of South Africa. Department of Mineral Resources (DMR). (2016). Draft Review of Mining Charter. [Online]. Available at: https://cer.org.za/wp-content/uploads/2010/08/Draft-reviewedMining-Charter.pdf. Accessed: 2018-01-07.

Republic of South Africa. Department of Energy (DoE). (2018). Minister of Energy to sign off 27 renewable energy projects, Press Release, March. [Online]. Available at: https://lowvelder.co.za/426023/minister-energy-sign-off-27-renewable-energy-projects/. Accessed: 2018-03-17.

76 Journal of Business Diversity Vol. 18(2) 2018 
Richards Bay Coal Terminal (RBCT). (2015). Annual Report.

Ryan, B. (2014). Mining new territory. Financial Mail, 27 March. [Online]. Available at:

http://www.financialmail.co.za/coverstory/2014/03/27/mining-new-territory-waterberg-coal-field. Accessed: 2017-11-10.

Sasol. (2008). Annual Report.

Sasol. (2015). Mozambique gas pipeline in US\$210 million expansion. Media releases. [Online]. Available at: http://www.sasol.co.za/media-centre/media-releases/mozambique-gas-pipelineus210-million-expansion. Accessed: 2017-11-15

Saunders, M., \& Lewis, P. (2012). Doing research in business management. London: Pearson Education.

Thopil, G. A., \& Pouris, A. (2010). An Overview of the electricity externality analysis in South Africa within the international context. South African Journal of Science, 106, (11), 23-28.

Union of Concerned Scientists, (2015). Each country's share of CO2 emissions. [Online]. Available at: https://www.ucsusa.org/global-warming/science-and-impacts/science/each-countrys-share-ofco2.html\#.WIDUtaiWbIV. Accessed: 2018-01-06.

United Nations Framework Convention on Climate Change (UNFCCC). (2009). Climate Change Accord, Copenhagen, Demark, December.

United Nations Conference on Environment Development (UNCED). (1992). Rio Declaration of Environment and Development, U.N. Doc. A/CONF.151/5/Rev.1. [Online]. Available at: http://heinonline.org/HOL/LandingPage?handle $=$ hein.journals/colenvlp4\&div $=12 \& \mathrm{id}=$ \&page $=$. Accessed: 2017-12-20.

World Bank Report. (2015). Coal role in electricity generation worldwide. [Online]. Available at: http://www.worldcoal.org/coal/uses-coal/coal-electricity. Accessed: 2017-12-20. 